\title{
EDITORIAL
}

\author{
CLIZIA CENTORRINO \\ Independent Scholar
}

MARCO DALLA GASSA

Ca' Foscari University of Venice

\section{With a hat and a red scarf: The construction of Federico Fellini's public image}

There are restaurants called 'La Dolce Vita' all over the world. Words like paparazzi have made it into dictionaries. Airports, streets, piazzas and schools are named after Federico Fellini. And yet, as cinema scholars understand, Fellini's films are not nearly as well-known as one might expect - even if university students will call him 'Maestro' without hesitation, when quizzed about the great directors in the history of cinema. There is almost no trace of Fellini on Amazon Prime or Netflix. In the best-case scenario, to most'millennials' and 'post-millennials' La Dolce Vita (1960) is not a film, but an image seen on Instagram or YouTube: Marcello Mastroianni and Anita Ekberg taking a dip in the Trevi Fountain, two unrivalled 'influencers' promoting the Italian brand and economic boom. In other words, far from being part of a'shared culture', 
Fellini's films have been reduced, over the course of time, to the clichés and stereotypes that feed the constellation of meanings surrounding the term 'Felliniesque', and this often discourages new (and updated) readings of his work.

The centenary of the birth of Federico Fellini 1920-2020 provided an ideal opportunity to fix this disconnect and introduce new generations to his fascinating films: the fruit of a truly artistic and visionary cinema and of an unrepeatable season of Italian cinema. A few steps were taken in that direction. At the beginning of 2020, as anticipated by the 'Studio Azzurro' exhibition Fellini 100, the city of Rimini inaugurated the Federico Fellini International Museum, a structure that 'will convey everything that cinema has wanted to be since its origin, reaching its fullest expression in Fellini's films: amazement, fantasy, spectacle, and fun' ('Rimini, la giunta comunale ufficializza l'istituzione del Museo Fellini', Il Resto del Carlino, 29 November 2019, https://www.ilrestodelcarlino.it/rimini/cronaca/rimini-fellini-museo-1.4897369) - at least in the words of the administration. Meanwhile, Rome celebrated Fellini with another important exhibition, curated by Dante Ferretti, at Cinecittà. There were a few screenings in movie theatres and a large retrospective at the British Film Institute, but all the launched or scheduled initiatives were ultimately overshadowed by the global Covid-19 emergency. Many projects were cancelled or postponed to better times. In the first months of the pandemic, the melancholy sight, at once distressful and sublime, of the deserted and windswept streets, piazzas and monuments of Rome and other Italian cities and provinces looked like a 'posthumous' scene by Fellini, like a joke played by the Maestro himself, or one of the many dream sequences that haunt his films. At the time of writing this introduction (April 2020), we can only hope that all the initiatives scheduled for the centenary (including books, documentaries, festival tributes and retrospectives) will eventually see the light of day, if they have not already. Most importantly, we hope for a renewed interest in Fellini's films, convinced as we are that they still have much to say, as the essays collected in this monograph attempt to demonstrate.

On the twentieth anniversary of Fellini's death, Frank Burke, one of the foremost scholars of the Italian director, suggested that future research should focus more on the historical, social and cultural context of his films (Burke 2016). Now that Fellini has been analysed and celebrated as the quintessential creative artist (a genius whose works can be entirely ascribed to his inner world), in light of the great categories of modernity and post-modernity, through the lens of psychoanalysis and within debates on cinematic realism, Burke argues that it is time to contextualize Fellini historically and culturally. The director is mostly studied in terms of his 'universality', i.e., independently from the social, political and productive context in which his films were shot. The power of his images is so overwhelming and larger-than-nature that his myth seems to resist any explanation based on New Historicism, following the model of Stephen Greenblatt's analyses of Shakespeare. Not by chance, Burke compares the director to Dante, Pirandello, Shakespeare and Joyce. He rightly observes that Fellini's works are rarely seen as 'Italian films from the 1950s' or simply as 'Italian films', and notes that even his own earlier works on Fellini (such as Federico Fellini: Variety Lights to La Dolce Vita) make hardly any reference to his historical context (Burke 2016: 17). Burke writes:

Here I limit myself to establishing parallels between Fellini's work and the word in which it is situated, thus falling prey to a kind of 'reflectionist fallacy': i.e., seeing his films only as reflections of his world and vice 
versa. My goal in the long term will be to address the full complexity of 'embeddedness': i.e. the ways in which his work and his world interrelate in history-making: the production of human significance that occurs at the intersection of multiple realities, influences, perceptions, actions, causes, and consequences.

(Burke 2016: 20)

In the last few years, various studies have sought to shed new light on Fellini's work, exploring under-investigated aspects and prioritizing the context, including the specific historical, cultural and political moment in which it is rooted (a partial selection of these studies is included in the references). This new literature clearly shows that today (more than in the past), his films can act as a formidable touchstone of Italianness, that is, of the Italian national character and ideology (and vice versa, Italianness is a touchstone of his films). In other words, there is an anthropological connection between his films and Italy. This connection is visible not only in the most evident and immediate aspects (such as Fellini's representation of Catholicism), but also in his take on the controversial nature of Italian modernity, with its exhilarating mixture of archaism and industrialization, gender relationships, the construction and assimilation of the memory of Fascism in collective imagery, and so forth.

The present issue of the Journal of Italian Cinema \& Media Studies (JICMS), dedicated to Federico Fellini, offers a step forward by complementing the historical approach (adopted by several of the articles included) with a cultural one that addresses the director's social value and public image. The centenary presents an opportunity to reflect also on Fellini's 'brand', i.e. on how the vast collection of discourses, imageries, values and stereotypes associated with his figure and name were circulated and sedimented in Italian and foreign visual cultures over the past 50 years. We believe - as we hope to prove, at least in part, in this Special Issue - that studying Fellini as a public figure, artist, Italian icon and cult director contributes a further element to our understanding of a body of work which, to this day, seems inseparable from its creator. From the formulation of the call for papers to our selection of articles, we followed, among others, the model established in Robert Kapsis' sociological study of the image of Hitchcock. In Kapsis' book, published in the early 1990s, publicity processes are understood as crucial to the construction of the cultural prestige associated with Hitchcock's work over the decades.

Assessing Fellini's aura is no easy task and will require further research in the years to come. Furthermore, like Hitchcock and, in Italy, perhaps only Pasolini, the director of Luci del varietà (Variety Lights) (Fellini 1951) facilitated and oriented the attention of scholars through a clever orchestration of his own public image. In particular, at least from the 1960s, he contributed to the creation of an elusive image of himself (Hodsdon 2017) both through the construction of several cinematic alter egos and through unmistakable appearances, wearing his hat and red scarf, in documentaries, feature films, illustrated news magazines, press and TV reports, as well as other forms of media. Fellini was keen on creating a public image of himself both as a magician and as a country bumpkin, playing with a combination of two Italian stereotypes: the creative artist (the 'maestro') and, in a sort of 'reverse patriotism', a heap of irredeemable flaws (Patriarca 2010). Similarly, he emerged as a staunch defender of certain political and cultural struggles, such as those against television commercials or against Berlusconi who was still a media entrepreneur at that time. In other words, he became an object of scrutiny 
and discussion for journalists, critics, cinephiles, colleagues and biographers searching for an openly hagiographical definition in the wake of the Italian artistic tradition.

Our decision to add these new contributions and voices to an already rich discursive sphere is due to the absence, in the past, of two important critical approaches that define a cultural study: the first, following Burke's example, involves abandoning any hagiographical or universalistic analysis of Fellini's public presence; the second involves the use of his public image as a lens to observe coeval social processes and phenomena in Italy beyond his creative sources, films and consolidated imageries. In other words, we sought to privilege an outward-looking attitude that transforms Fellini from a clairvoyant who conjures up supernatural entities (i.e. poetic, brilliant, symbolic and rarefied) into a mediator who incarnates, connects, interferes with and 're-tweets' complex, chaotic and blurred social bodies.

In the first article of the issue, for instance, Marco Bertozzi takes us on a Debordian flânerie through the space and architecture of Rimini. The journey begins in the footsteps of the 'Maestro' in his hometown, but Bertozzi quickly 'loses' himself in a kind of cinematic and urban mediascape where points of view, changing habits and lifestyles and the inner contradictions of the director and his city form extraordinary and fascinating stratifications.

In a way, the trajectory chosen by Damiano Garofalo and Angela Mancinelli takes us to the same destination. Their article starts by tracing the organic relationship between Fellini and television through a detailed overview of the references to the latter medium in his films, and of his own controversial televised appearances. It then proceeds to show how the contradictions of this relationship (Fellini was a vocal detractor of commercial breaks, though he also directed commercials) gave voice to the tensions between the iconophilia and iconophobia of the emerging Berlusconi era. Fellini also becomes the mouthpiece of the conflicts and contradictions of another historical moment in Italy, namely the emergence of feminist movements. Francesca Cantore and Giulia Muggeo address this, analysing the attacks against Fellini by several feminist journals after the release of La città delle donne (City of Women) (Fellini 1980). The artist's symbolic capital triggers a heated debated on gender identity and on the rhetoric associated with the alluring, stereotypical and sexist charm of the Latin Lover.

The articles by Joanna Staśkiewicz and Ivan Pintor Iranzo take us on an original journey through Fellini's iconography, leading to unexpected destinations. Staśkiewicz starts from Gelsomina, the character played by Giulietta Masina in La Strada (1954), retracing her iconic persistence in the figure of the 'female clown' in contemporary Neo-burlesque; Iranzo focuses instead on representations of Fellini in comics and interprets his appearances 'on paper' as a humanization of Hermes, messenger of the Gods, symbol of the journey experience and father of hermeneutics. Stephan Ahrens and Valerio Coladonato step quite literally into foreign lands: Ahrens retraces the critical reception of Fellini in 1950s Germany, where the director inspired a formal renewal which eventually led to the Neuer Deutscher Film; Coladonato focuses on how the Cannes film festival, in the same years, contributed to building Fellini's authoriality through its programming and critical reception. Finally, Barbara Corsi, Marina Nicoli and Alfonso Venturini go beyond the momentum of auteur theory to examine how Fellini became a 'brand', especially in terms of production enterprises such as Cineriz. 
Hermes, clown, provocateur, flâneur, brand, mouthpiece, Latin lover: whatever the implicit or explicit metaphor chosen by the authors of this issue, Fellini always appears as a mediator placed inside a wide discursive sphere that encompasses the history of Italian customs and society. Of course, Fellini's intransigence and unwillingness to compromise makes him quite an unusual model for a mediator.

The following anecdote from the last months of Fellini's life is possibly the best expression of the challenge that his public image represents for scholars. In 1993, the University of Bologna gave him an honorary degree, which was quite an honour at that time. However, Fellini politely declined. In a long letter addressed to the University Rector, he asked him to ascribe his refusal not to snobbery, superficiality or arrogance ('as if I didn't want to acknowledge the importance that others attribute to my work'), but to the fact that it made him somewhat uncomfortable. 'I must confess to you that I feel like Pinocchio being decorated by the headmaster and carabinieri for cavorting in Pleasure Island'. The transgressor who received accolades from Institutions, the artist who infuriated in turn communists, Christian democrats, bishops, fascists, neorealists and feminists only to be eventually celebrated with fanfare, attention from mayors, national anthems and Italian flags, ultimately did not want to forsake his role as Lampwick or, if we prefer, as Titta Biondi in Amarcord.

Today, especially in light of the articles collected here, his attitude strikes us as a means to maintain the role of mediator which, with all its irreverence and contradictions, could not be performed from a pedestal.

To finish, the editors would like to thank Flavia Laviosa and the board of the JICMS, for having accepted the proposal of this Special Issue and having supported it in all phases of its completion. We are also grateful for the scrupulous work of the peer reviewers, and the assistants who worked on this issue with great dedication from start to finish: Rory McKenzie, Victoria University of Wellington, New Zealand, Glen Bonnici, University of Malta, Megan D'Alessandro, Wellesley College and Jim Carter, University of Michigan.

The title 'With a hat and a red scarf' is a tribute to Errore Scola's drawing of one of the most iconic images of the director. We wish to thank Gigliola, Paola and Silvia Scola for granting permission to use it as the cover of this Special Issue of JICMS on Federico Fellini.

During the editing of this issue, we have had news of Paolo Fabbri's death. Fabbri, born in Rimini, is one of the most important Italian semiologists and director of the Federico Fellini foundation. We dedicate our 'Amarcord' to his memory, his extraordinary scholarly contribution and his curiosity for the world.

\section{REFERENCES}

Bondanella, Peter (2002), The Films of Federico Fellini, Cambridge: Cambridge University Press.

Burke, Frank (1984), Federico Fellini: Variety Lights to La Dolce Vita, Boston: Twayne.

Burke, Frank (2016), 'Herding cats: Putting Fellini's films into historical perspective(s)', in P. Bernardini, J. Granata, T. Lobalsamo and A. Zambenedetti (eds), Federico Fellini: Riprese, riletture, (re)visioni, Firenze: Franco Cesati Editori, pp. 17-37.

Burke, Frank and Waller, Marguerite (eds) (2002), Federico Fellini: Contemporary Perspectives, Toronto: University of Toronto Press. 
Burke, Frank, Waller, Marguerite and Gubareva Marita (eds) (2020), A Companion to Federico Fellini, London: Wiley-Blackwell.

Greenblatt, Stephen (2004), Will in the World: How Shakespeare Became Shakespeare, New York and London: W.W. Norton \& Company.

Hodsdon, Barrett (2017), The Elusive Auteur: The Question of Film Authorship Throughout the Age of Cinema, Jefferson, NC: McFarland \& Company, Inc. Publishers.

Kapsis, Robert E. (1992), Hitchcock: The Making of a Reputation, Chicago: University of Chicago Press.

Marcus, Millicent (2002), After Fellini: National Cinema in the Postmodern Age, Baltimore: Johns Hopkins University Press.

Patriarca, Silvana (2010), Italian Vices: Nation and Character from the Risorgimento to the Republic, Cambridge: Cambridge University Press.

Stubbs, John C. (2015), Federico Fellini as Auteur: Seven Aspects of His Films, Carbondale: Southern Illinois University Press.

\section{CONTRIBUTOR DETAILS}

Clizia Centorrino, an independent scholar, holds a Ph.D. in cinema studies from the University Grenoble Alpes, where she has been a teaching assistant. Her research interests lie in Italian cinema, documentary, cinema and psychoanalysis, and experimental cinema. She has published chapters in the volumes Fictional Artworks: Literary Ékphrasis and the Invention of Images (V. Cammarata and V. Mignano [eds], Mimesis International, 2016) and TuttoFellini (E. Giacovelli [ed.], Gremese, 2019); and articles in the academic journals Cinergie and L'avventura. She has also curated the retrospectives of Italian cinema at the Cinémathèque de Grenoble: Elio Petri et le cinéma de la névrose in 2019, Rétrospective Ermanno Olmi in 2018 and Rétrospective Leonardo Di Costanzo in 2017; the film festivals: L'excentrique cinema in Grenoble in 2019; the section Album Boris Lehman for Archivio Aperto in Bologna in 2019; and the section Pellicola in scena for the Turin Fringe Festival in 2019, dedicated to analogic performances in $16 \mathrm{~mm}$ and super $8 \mathrm{~mm}$.

E-mail: clizia.centorrino@univ-grenoble-alpes.fr

(1) https://orcid.org/0000-0002-6408-3875

Marco Dalla Gassa is assistant professor at the Università Ca' Foscari in Venice. $\mathrm{He}$ is a film scholar whose research focuses on Asian cinema, orientalism, film festivals, auteur theory and film analysis. He is the author of two monographs: Abbas Kiarostami (Le Mani, 2001) and Il cinema di Zhang Yimou (Le Mani, 2003, co-authored with Fabrizio Colamartino), Il cinema dell'Estremo Oriente. Cina, Corea del Sud, Giappone, Hong Kong, Taiwan, dagli anni Ottanta ad oggi (Utet, 2010, co-authored with Dario Tomasi), an analysis of Kurosawa's masterpiece Rashōmon (Lindau, 2012) and Orient to Express (Mimesis, 2016) about orientalism and exoticism in modernist European cinema. He is also co-curator for the book series Biblioteca: Cinema, Media e Studi Culturali for Meltemi Press.

Contact: Dipartimento di Filosofia e Beni Culturali, Palazzo Malcanton Marcorà, Università Ca' Foscari di Venezia, Dorsoduro 3484/D, 30123 Venice, Italy.

E-mail: dallagas@unive.it

(D) https://orcid.org/0000-0003-0218-1813 
Andrea Minuz is associate professor of film and media history at Sapienza University of Rome, Department of Art History and Performing Arts. His research focuses on Italian film history, media industry and production studies. He has published essays in multi-authored volumes and various articles in academic journals. His books as author include La Shoah e la cultura visuale. Cinema, memoria, spazio pubblico (Bulzoni, 2010); L'invenzione del Luogo. Spazi dell'immaginario cinematografico (ETS, 2011); Viaggio al termine dell'Italia. Fellini politico (Rubbettino, 2012), Political Fellini. Journey to the End of Italy (translated from the Italian by Marcus Perryman, Berghahn, 2018); and Quando c'eravamo noi. La crisi della sinistra nel cinema italiano da Berlinguer a Checco Zalone (Rubbettino, 2014). He is co-curator for the book series titled Italian Frame for Mimesis.

Contact: Facoltà Storia dell'arte e spettacolo, Sapienza Università di Roma, Via dei Volsci 122, 00185 Rome, Italy.

E-mail: andrea.minuz@uniroma1.it

(1) https://orcid.org/0000-0003-2290-2980

Clizia Centorrino, Marco Dalla Gassa and Andrea Minuz have asserted their right under the Copyright, Designs and Patents Act, 1988, to be identified as the authors of this work in the format that was submitted to Intellect Ltd. 